\title{
Coming to Terms with a Violent Past
}

\author{
TANJA PENTER
}

Miriam Dobson, Khrushev's Cold Summer: Gulag Returnees, Crime, and the Fate of Reform after Stalin. 264 pp. Ithaca, NY: Cornell University Press, 2009. ISBN-13 978-0801447570. \$45.00.

Bettina Greiner, Verdrängter Terror: Geschichte und Wahrnehmung sowjetischer Speziallager in Deutschland (Terror Displaced: The History and Perception of Soviet Special Camps in Germany). 525 pp. Hamburg: Hamburger Edition, 2010. ISBN-13 978-3868542172. €35.00.

As recent case studies on the topic of transitional justice have demonstrated, recovery from the experience of mass violence and political terror and coming to terms with the associated past always constitute lengthy and painful processes, often including contradictions as well. ${ }^{1}$ Contributing to this developing field of research, the works of Miriam Dobson and Bettina Greiner focus on the history and public perception of the Stalinist camps and their inmates in the USSR and in the Soviet zone of occupation that later became the German Democratic Republic (GDR). Both works seek to understand individual perceptions of the camp experience and various attempts of state, societies, and individuals to come to terms with a past characterized by terror and totalitarian dictatorship.

After Stalin's death in 1953, hundreds of thousands of Gulag prisoners were released by amnesty. Between 1953 and 1960, the population of the Gulag fell dramatically from 2.5 million to 0.5 million. This exodus included not only victims of the Stalinist purges but also ordinary criminals. In her impressive monograph, Dobson explores the massive departure of prisoners from the Gulag and popular reactions to this process among those to whom

\footnotetext{
${ }^{1}$ For a theory of transitional justice, see Ruti G. Teitel, Transitional Justice (Oxford: Oxford University Press, 2000).
}

Kritika: Explorations in Russian and Eurasian History 14, 3 (Summer 2013): 683-90. 
the prisoners returned. Presenting the Gulag releases as an event that affected all of society, the book fruitfully combines three different aspects of the problem: the reform policies of Khrushchev and other political leaders; ordinary peoples' perceptions of de-Stalinization and Gulag release; and returnees' perceptions and experiences of life in the postcamp world. Her work accords with a general shift of interest in recent research on the Gulag, which concentrates on the post-Stalinist era and the "dilemmas of de-Stalinization." Dobson skillfully combines the different perspectives in her book and shows us the big picture of politics and society coping with the results of Stalinist terror. She thus offers insights into everyday life, social and political tensions, and patterns of exclusion and inclusion in the USSR after Stalin.

While Dobson focuses on processes within the USSR, Bettina Greiner investigates the history of Soviet special camps located on the territory of the Soviet zone of occupation and the GDR in the years from 1945 to 1950. Research on the special camps developed in Germany only in the 1990s, when for the first time the Russian archives opened their collections to foreign researchers. By the end of that decade, some primary research and an edition of documents about the special camps had appeared. ${ }^{3}$ Greiner's monograph represents a continuation of this trend.

In numerical terms, these camps were much smaller than those located in the USSR itself. According to official Soviet accounts, around 160,000 civilian men and women were imprisoned in ten camps, among them prominent resistance fighters like Ulrich Freiherr von Sell (a participant in the plot on Hitler's life of 20 July 1944) and Horst von Einsiedel (a member of the Kreisau Circle, mostly conservative Germans who had opposed Nazism). Most of the prisoners were Germans, while another 35,000 or so were Soviet

${ }^{2}$ See Polly Jones, ed., The Dilemmas of De-Stalinization: Negotiating Cultural and Social Change in the Khrushchev Era (London: Routledge, 2006); Nanci Adler, The Gulag Survivor: Beyond the Soviet System (New Brunswick, NJ: Transaction Books, 2002); Marc Elie, "Les anciens detenus du Goulag: Liberations massives, reinsertion et rehabilitation dans l'URSS poststalinienne, 1953-1964" (Ph.D. diss., École des hautes etudes en sciences sociales, 2007); Amir Weiner, "The Empires Pay a Visit: Gulag Returnees, East European Rebellions, and Soviet Frontier Politics," Journal of Modern History 78, 2 (2006): 333-76; Meinhard Stark, Die Gezeichneten: Gulag-Häftlinge nach der Entlassung (Berlin: Metropol, 2010); and Mirjam Sprau, "Leben nach dem Gulag: Petitionen ehemaliger sowjetischer Häftlinge als Quelle," Vierteljahrshefte für Zeitgeschichte, no. 1 (2012): 93-110. See also the thematic volume "Aufbruch aus dem Gulag," Jahrbücher für Geschichte Osteuropas 57 (2009).

3 Sergej Mironenko, Lutz Niethammer, and Alexander von Plato, eds., Sowjetische Speziallager in Deutschland 1945 bis 1950, 1: Studien und Berichte; 2: Sowjetische Dokumente zur Lagerpolitik (Berlin: Akademie, 1998). For convictions of around 35,000 Germans by Soviet military tribunals between 1945 and 1955, see also Andreas Hilger, Mike Schmeitzner, and Ute Schmidt, eds., Sowjetische Militärtribunale, 2: Die Verurteilung deutscher Zivilisten 1945-1955 (Cologne: Böhlau, 2003). 
citizens. Mortality in these camps was extremely high, reaching 35 percent; nearly 43,000 prisoners died from hunger and disease during their prison terms. In her case study, Greiner focuses specifically on Sachsenhausen, which had more than 60,000 prisoners and was thus the biggest special camp in the Soviet zone of occupation. The camp inmates can be divided into two groups. The first were the so-called internees, who were incarcerated for years without trial and consisted mostly of former Nazis. The second, smaller group comprised the convicts of Soviet military tribunals. The prisoners of the special camps simultaneously included perpetrators of crimes and their victims, both followers and opponents of National Socialism. The Nazi past of some camp inmates helps explain why the former prisoners have still not been publicly acknowledged as victims of a totalitarian regime and why they were-according to their own view—perceived as "second-class victims" (40).

Much like the Soviet Gulag prisoners, who were excluded from the official Soviet memory culture until the end of the USSR, the Soviet special camps in Germany continue to represent a rather marginal topic of the German culture of memory even today. This goes along with a general lack of knowledge about the history of the Soviet Gulag among the German public. ${ }^{4}$ More than six decades after the end of World War II, as Greiner concludes, the special camps are still often accorded a certain moral legitimacy and are seen to have fulfilled a necessary political function of de-Nazification. Nonetheless, at least in the Federal Republic of Germany the former prisoners of the special camps achieved a certain recognition as the "first victims of the Cold War" in the 1950s-60s because of widespread anticommunist sentiment. In this context, Greiner discusses the still understudied role of the Group for the Struggle against Inhumanity (Kampfgruppe gegen Unmenschlichkeit, $\mathrm{KgU}$ ), an institution of the Cold War, which existed from 1948 to 1959 and was partly financed by the U.S. intelligence services. The $\mathrm{KgU}$ offered former prisoners of Soviet special camps a meeting place and a public forum for the discussion of their experiences. It collected more than 4,000 camp testimonies, which constitute a valuable collection of witness accounts. These are an important source for Greiner's book.

Dobson and Greiner both draw on personal accounts and letters in their studies to show us the individual perceptions and subjective perspectives of people coming to terms with experiences of dictatorship and violence. Focusing on materials like letters to editors, the deliberations of party leaders

\footnotetext{
4 Actually the exhibition "Gulag: Spuren und Zeugnisse 1929-1956" (a cooperation of Memorial Moscow and the Stiftung Gedenkstätten Buchenwald und Mittelbau-Dora) for the first time shows exhibits of the Soviet camp system to a broader German public. See the catalogue, Gulag: Spuren und Zeugnisse 1929-1956 (Göttingen: Wallstein, 2012).
} 
and other party and state institutions, as well as on newspaper editors' summaries of letters from readers and party reports on the popular mood, Dobson shows us a fascinating and diverse set of responses to the reforms under Khrushchev. More generally, she sheds light on the Soviet attempt to come to terms with the traumatic legacies of Stalin's terror. Analyzing the letters of ordinary citizens and Gulag returnees, Dobson recognizes these letters as "artifacts, purposefully created and intended for a specific audience," which nevertheless at the same time "offer insight into the author's worldview" (12). Petitions of ordinary citizens to the organs of power have a long tradition in the Soviet Union and in imperial Russia. They represent a specific form of political communication and are generally characterized by certain semantics, rhetoric, and patterns of self-representation. ${ }^{5}$ The petitions tell us a good deal about specific everyday life problems of the returning former Gulag prisoners (such as finding housing or work) as well as about the fears and interests of the local societies and practices of stigmatization and discrimination. Yet their informative value for questions of loyalty and general worldview might be disputed.

Greiner's materials are in a sense similar. Drawing mainly on more than 100 autobiographical accounts by former camp inmates (mostly materials published from the 1950s), she offers a detailed picture of the everyday experiences of the prisoners inside the camps, including barely researched aspects of their lives such as internal camp hierarchies, informers and prisoners with special functions, and sexuality. Following the theoretical approach of Wolfgang Sofsky, Greiner examines the everyday life of the prisoners as an all-embracing experience of violence, starting with arrests and interrogations by the People's Commissariat of Internal Affairs (NKVD), continuing with life in the camps, and difficult social reintegration after release. Greiner asks whether the inner dynamics of the camp community, characterized as it was by force and shortages of basic goods, promoted brutalization and mutual

\footnotetext{
5 Among others, see Sheila Fitzpatrick, "Supplicants and Citizens: Public Letter-Writing in Soviet Russia in the 1930s," Slavic Review 55, 1 (1996): 78-105; G. L. Freeze, ed., From Supplication to Revolution: A Documentary Social History of Imperial Russia (Oxford: Oxford University Press, 1988); Juliane Fürst, "In Search of Soviet Salvation: Young People Write to the Stalinist Authorities," Contemporary European History 15, 3 (2006): 327-34; Gleb Tsipursky, "As a Citizen, I Cannot Ignore These Facts': Whistleblowing in the Khrushchev Era," Jahrbücher für Geschichte Osteuropas 58, 1 (2010): 52-69; Margarethe Mommsen, Hilf mir mein Recht zu finden: Russische Bittschriften von Iwan dem Schrecklichen bis Gorbatschow (Frankfurt: Propyläen, 1987); Ekaterina Surovtseva, Zhanr "pis'ma vozhdiu" v sovetskuiu epokhu (1950-e-1980-e gg.) (Moscow: AIRO-XXI, 2010); Surovtseva, Zhanr "pis'ma vozhdiu" $v$ totalitarnuiu epokhu (1920-e-1950-e gg.) (Moscow: AIRO-XXI, 2008); and A. Ia. Livshin and I. B. Orlov, eds., Pis'ma vo vlast', 1917-1927: Zaiavleniia, zhaloby, donosy, pis'ma v gosudarstvennye struktury i bol'shevistskim vozhdiam (Moscow: Rosspen, 1998).
} 
stigmatization among the prisoners. She shows that despite the evocations of comradeship in some of the prisoners' memoirs, there was rarely any solidarity among the camp inmates, a circumstance sometimes rooted in different political orientations and attitudes toward National Socialism. Moreover, Greiner convincingly deconstructs the narrative strategies of prisoners' camp memoirs, which were often characterized by an attempt to inscribe themselves into a publicly recognized image of victims, leaving out all aspects that did not fit into this template. Dobson discovered similar narrative strategies in letters by former Gulag prisoners to Soviet authorities (57).

As these two studies show, the recognition and reintegration of Stalinism's victims encountered certain limits in both German and Soviet society, although for different reasons in each place. Looking at the public reactions to the Gulag release, Dobson shows that Soviet citizens responded quite variously to de-Stalinization and the return of Gulag prisoners, who were sometimes hardened criminals, alienated and embittered by their camp experiences. Frightened by rising crime rates, some Soviet citizens reacted to the Gulag exodus with moral panic and refused to accept the former "enemies of the people" into local communities. Some letter writers complained about public confidence being shaken by Stalin's death and the Gulag release, calling 1953 the "most painful year of all we have lived through" (30).

The special achievement of Dobson's work is to show us ordinary people's subjective perceptions in coping with Stalinist repressions, whereas older research on the Gulag mostly focused on memory literature and/or archival documents of the Gulag administration, which have been accessible to historians since the 1990s. ${ }^{6}$ Revising older concepts of the "Thaw," Dobson points out that the period was at once "forward-looking, ambitious, and full of hope" and "disorienting and potentially unsettling" (15). Her main argument is that in the Soviet Union under Khrushchev, reform policies of de-Stalinization finally failed in 1961, because the majority of the Soviet society was mentally not ready for them. Ordinary Soviet citizens actively opposed the reintegration of former Gulag prisoners into society.

In Germany, according to Greiner, public acknowledgment of former special camp inmates as "political prisoners at Stalin's mercy" (472) did not take place until recently, primarily because many people still think of the camps as a legitimate instrument for de-Nazification. Trying to deconstruct

\footnotetext{
${ }^{6}$ For an overview on Gulag research, see Nicolas Werth, "Der Gulag im Prisma der Archive: Zugänge, Erkenntnisse, Ergebnisse," Osteuropa 57, 6 (2007): 9-30. For an extensive edition of Gulag archival documents, see Iurii N. Afanas'ev et al., eds., Istoriia stalinskogo Gulaga: Konets 20-kh-pervaia polovina 1950-kh godov. Sobranie dokumentov, 7 vols. (Moscow: Rosspen, 2004).
} 
this widespread interpretation, Greiner analyzes the political function of the special camps in Germany: did they constitute a legitimate instrument for deNazification, or were they rather an instrument of terror designed primarily to secure the rule of occupational authorities? As Greiner concludes, Soviet policies followed primarily considerations of prophylaxis against potential enemies and internal logics of NKVD repressions. The persecution of Nazi perpetrators was not the main goal of Soviet occupational authorities. Therefore, only one of five convicts of Soviet military tribunals was sentenced for Nazi crimes. The camps fulfilled for the Soviet authorities mainly security functions and therefore differed significantly from the internment camps of the Western allies in their political priorities (471). Here Greiner's argument converges with previous findings about the high degree of politicization of Soviet practices of prosecution and conviction in the Soviet zone of occupation and early GDR. ${ }^{7}$ Hopefully, a further systematic study of case files of special camp prisoners-located in Russian archives and unfortunately still inaccessible-might eventually bring further insights in this regard.

Quite exhilarating is Greiner's detailed discussion of denunciations, which were supported by Soviet authorities. In many cases, prisoners of the German special camps were arrested on the basis of denunciations by their neighbors. These reflected various motivations, such as jealousy, envy, conflicts at work, demonstrative proclamations of loyalty, or the wish of former victims of National Socialism for revenge. On the whole, by encouraging and supporting these denunciation practices, the Soviet occupational authorities created an overall atmosphere of fear, as Greiner shows convincingly.

$$
\text { ㄴ }
$$

Reading these two well-written books in parallel offers many interesting comparative insights about how individuals cope with experiences of repression and how societies come to terms with a violent past. A research desideratum remains a comparative analysis of the different Stalinist camp systems of the Gulag and the Main Administration for the Affairs of Prisoners of War and Internees (GUPVI) and special camps in the Soviet zone of occupation/ GDR, as well as Nazi camps and camps of the Western allies, which Greiner discusses rather cursorily in her concluding remarks. So far, historical research in this comparative field has concentrated on those camps in Germany that served as both Nazi concentration camps and later NKVD special camps (e.g., Sachsenhausen and Buchenwald). ${ }^{8}$ The comparison shows evident

\footnotetext{
7 Hilger, Schmeitzner, and Schmidt, Sowjetische Militärtribunale, vol. 2.

${ }^{8}$ See, among others, Peter Reif-Spirek and Bodo Ritscher, eds., Speziallager in der SBZ: Gedenkstätten mit doppelter Vergangenheit (Berlin: Links, 1999); Annette Leo, "Überlegungen
} 
differences. For example, the NKVD special camps in Germany did not use forced labor. In contrast to the Nazi concentration camps and the camps of the Stalinist Gulag, where forced labor constituted one of the main elements of everyday life, for some prisoners of special camps, work even constituted a privilege, while most of the prisoners suffered from total inactivity and isolation. ${ }^{9}$ It should also be noted that the concept of Vernichtung durch Arbeit (physical destruction through work) was rather specific to the Nazi concentration camps.

Concerning the matter of forced labor, I should also mention here that in the main Soviet industrial regions after World War II, different types of camps for Soviet citizens and foreigners coexisted next to each other. For example, an array of camps was installed in the Donbass coal basin, where unfree workers lived and worked under highly diverse conditions. Quite often in Soviet postwar reconstruction, the borders between free and unfree labor were fluid; ironically, the living conditions of the free workers were sometimes worse than those of the unfree laborers. ${ }^{10}$

In the postwar years, several hundreds of thousands of Gulag prisoners were convicted as traitors to the homeland: for example, policemen who collaborated with the Germans in the occupied territories and sometimes even participated in German mass murders. ${ }^{11}$ More research is needed to determine how this new "element" among the Gulag prisoners influenced everyday life in the camps and perhaps made the reintegration of Gulag returnees into society even more difficult.

Finally, an interesting approach for further research might be to "release the history of the Gulag from solitary confinement," as Kate Brown suggested, and compare it, for example, to the continuum of U.S. disciplinary and penal

zu einem Vergleich des nationalsozialistischen Konzentrationslagers Sachsenhausen 1937 bis 1945 mit dem sowjetischen Speziallager Sachsenhausen 1945 bis 1950," in Materialien der Enquete-Komission "Überwindung der Folgen der SED-Diktatur im Prozeß der deutschen Einheit," 6: Gesamtdeutsche Formen der Erinnerung an die beiden deutschen Diktaturen und ihre Opfer (Baden-Baden: Nomos, 1999), 441-89; Lutz Niethammer, "Buchenwald: KZ und NKWDLager. Der Zeithistoriker im Konflikt mit Zeitzeugen,” Zeitschrift für Geschichtswissenschaft 54. 12 (2006): 1039-53. For a volume that combines research articles on the Nazi camp system and the Stalinist Gulag, see Dittmar Dahlmann and Gerhard Hirschfeld, eds., Lager, Zwangsarbeit, Vertreibung und Deportation: Dimensionen der Massenverbrechen in der Sowjetunion und in Deutschland 1933 bis 1945 (Essen: Klartext, 1999).

9 Niethammer, "Buchenwald," 1044.

10 Tanja Penter, Koble für Stalin und Hitler: Leben und Arbeiten im Donbass, 1929 bis 1953 (Essen: Klartext, 2010).

11 On this question, see Tanja Penter, "Local Collaborators on Trial: Soviet War Crimes Trials under Stalin (1943-1953)," Cahiers du monde russe 49, 2-3 (2008): 341-64. 
practices, which contributed to the development of a legally bounded welfare state. $^{12}$

$$
\text { cra }
$$

The studies by Dobson and Greiner enlarge our understanding of camp history mainly in two ways. First, they show us the desirability of extending our analysis to the aftermath of the camp, including questions of social reintegration and rehabilitation of former prisoners and changes of (memory) policies. Second, they fruitfully combine perspectives on the state's penal policies and everyday life practices with the level of subjective perceptions and memory. In this respect, the two works represent an important contribution to the history of camps, political terror, and their long-term consequences.

Professur für Geschichte des 19. und 20. Jahrhunderts unter besonderer

Berücksichtigung Mittel- und Osteuropas

Helmut-Schmidt-Universität

22043 Hamburg, Germany

penter@hsu-hh.de

12 Kate Brown, "Out of Solitary Confinement: The History of the Gulag," Kritika 8, 1 (2007): 67-103. 